\title{
HEINONLINE
}

Citation: 114 Harv. L. Rev. 2098 2000-2001

Content downloaded/printed from

HeinOnline (http://heinonline.org)

Fri May 25 13:21:30 2012

-- Your use of this HeinOnline PDF indicates your acceptance of HeinOnline's Terms and Conditions of the license agreement available at http://heinonline.org/HOL/License

-- The search text of this PDF is generated from uncorrected OCR text.

-- To obtain permission to use this article beyond the scope of your HeinOnline license, please use:

https://www.copyright.com/ccc/basicSearch.do?

\&operation $=$ go\&search Type $=0$

\&lastSearch $=$ simple\&all=on\&titleOrStdNo $=0017-811 \mathrm{X}$

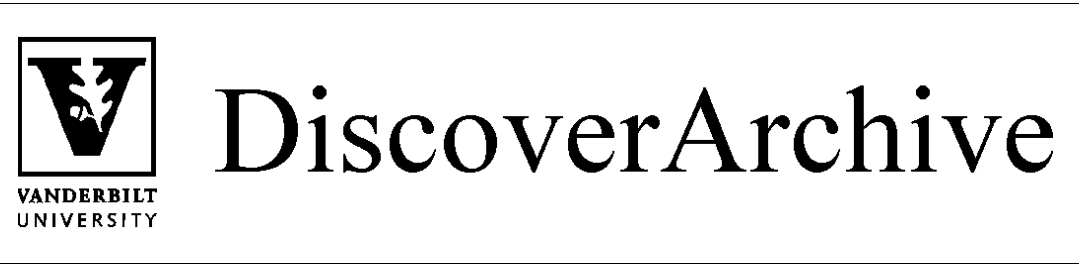

Retrieved from DiscoverArchive,

Vanderbilt University's Institutional Repository

Please note that the copyright in the Harvard Law Review is held by the President and Fellows of Harvard College, and that the copyright in the article is held by the author. 


\section{CONSTITUTIONAL RISKS TO EQUAL PROTECTION IN THE CRIMINAL JUSTICE SYSTEM}

Historically, the Supreme Court has required a showing of particularized harm to prove an equal protection violation. For example, in McCleskey $v$. Kemp, ${ }^{1}$ the Supreme Court found no equal protection violation $^{2}$ despite statistical studies showing that defendants charged with killing white victims were four times more likely to be sentenced to death than those charged with killing black victims. ${ }^{3}$ The Court reasoned that these statistics did not demonstrate that racial considerations had played a role in McCleskey's particular sentence. ${ }^{4}$ Although the requirement of particularized harm is consistent with the traditional common law view of causation, it necessarily causes courts to neglect more subtle, systemic risks created by the operation of government. Often a criminal defendant cannot identify a specific wrongdoer, nor can he prove that racial discrimination more likely than not tainted his particular conviction. ${ }^{5}$ Sometimes, as in McCleskey, all that a defendant can show is that, after multipleregression analyses have accounted for plausible non-racial explanations, disparities still remain.

The requirement of particularized harm is of special concern in equal protection cases today as social mores have largely driven racial animus underground, making discrimination far more likely to occur surreptitiously: ${ }^{6}$ This problem is exacerbated in the criminal justice context, in which government actors often wield vast amounts of discretion - discretion that allows those who discriminate to mask their

148 I U.S. 279 (1987).

2 Id. at 299.

3 See id.

4 See id. at 294-95, 297.

5 See Alan David Freeman, Legitimizing Racial Discrimination Through Antidiscrimination Law: A Critical Review of Supreme Court Doctrine, 62 MINN. L. REV. 1049, I056 (1978) (noting the "impossible burden of isolating the particular conditions of discrimination produced by and mechanically linked to the behavior of an identified blameworthy perpetrator"); $c f$. Herskovits v. Group Health Coop. of Puget Sound, 664 P.2d 474, 475 (Wash. r 983) (addressing the causation problems when a doctor's negligent diagnosis reduced a cancer patient's chance of survival); Sindell v. Abbott Labs., 607 P.2d 924, 927-28 (Cal. 1980) (addressing the claims of a plaintiff who was unable to identify precisely which pharmaceutical company manufactured a defective drug).

6 Some commentators additionally, albeit controversially, suggest that racism can exist unconsciously, caused by a lack of empathy. See, e.g., Paul Brest, The Supreme Court, 1975 TermForeword: In Defense of the Antidiscrimination Principle, 9o HARV. L. REV. I, 14-15 (1976) (describing the problem of "racially selective indifference"); Charies R. Lawrence III, The Id, the Ego, and Equal Protection: Reckoning with Unconscious Racism, 39 STAN. L. REV. 31 7, 328-44 (1987). But cf., e.g., Md. Troopers Ass'n v. Evans, 993 F.2d 1072, 1077 (4th Cir. 1993) (distinguishing "cronyism" from racism in a Title VII action because, although selecting one's friends may result in numerical disparities, "it is not the same kind of iniquity as racial discrimination"). 
impermissible motives. ${ }^{7}$ Ironically, the harm that particularized inquiries are thus most likely to overlook is one that is especially damaging to the legitimacy of the law: systemic racial discrimination in the administration of criminal justice.

This Note examines the reasons for and the ramifications of a new equal protection perspective that would recognize not only traditional particularized harms, but also risks - uncertain, probabilistic representations of traditional harms. ${ }^{8}$ Rather than ignoring risk as an unremediable possibility of harm, the new paradigm would view risk as a harm in itself. 9 A constitutional risk perspective would not necessarily change any underlying values or normative goals of the legal system, but it would enhance the law's ability to recognize a set of harms hidden by the current paradigm of particularity. It would allow a reassessment of "the legal significance of discrete, isolated decisions that are susceptible to a non-racial explanation when considered individually, but reveal a pattern clearly shaped by racial sentiment when considered en masse."10

Part I summarizes the traditional requirement of particularity: its underlying reasons, its costs, and its effect on racial discrimination claims related to sentencing, prosecution, and policing. A brief examination reveals that the particularity requirement unnecessarily causes courts to ignore statistical data and to fail to remedy systemic discrimination. Part II conceptualizes a regime of constitutional risk and addresses the difficult problem of providing an appropriate remedy. In a regime that recognized risks as harms, defendants could make claims for less than certain, probabilistic harms, so delineating proper remedies would therefore be crucial to prevent a collapse of the system. Part II argues that guidelines for the exercise of discretion may create the right balance between security against discrimination and practical flexibility. Part III discusses the possibilities for a constitutional risk regime and suggests areas for further research.

7 See infra note 110 .

8 Cf. Laurence H. Tribe, The Curvature of Constitutional Space: What Lawyers Can Learn from Modern Physics, Io3 HARV. L. REV. I, 12 (I989) (advocating a shift in state action doctrine from a Newtonian world view focused on "isolated forces acting on particular individuals" to a post-Newtonian, relativistic view focused on individuals' interactions with the entire fabric of a system).

9 Cf. Herskovits, $66_{4}$ P.2d at 481 (Pearson, J., concurring) (suggesting that the "injury" caused by a doctor's negligent diagnosis could be defined as the decreased chance of surviving cancer).

10 Randall L. Kennedy, McCleskey v. Kemp: Race, Capital Punishment, and the Supreme Court, IOI HARV. L. REV. 1388, 1406 (1 988). 


\section{The PARTICULARITY REQUiREMENT}

Equal protection doctrine generally requires both a particularized actor and a particularized harm: a litigant must prove not only that a government actor was motivated by a discriminatory purpose, ${ }^{11}$ but also that the discriminatory act affected the outcome of his case. ${ }^{12}$ The Court has adhered rigidly to these particularity requirements, inducing some commentators to describe the doctrine as limiting equal protection violations only to cases in which a government official is "out to get" an individual based on impermissible grounds. ${ }^{13}$ Except in a few select areas, ${ }^{14}$ statistical evidence rarely furnishes a basis for a successful equal protection claim. ${ }^{15}$

\section{A. The Reasons for Particularity}

The reluctance of courts to grant relief based on statistical showings of inexplicable racial disparities is not without reasonable basis. The requirement of particularity is closely linked to traditional Enlightenment notions of moral responsibility and free will, and a rush to embrace statistical data could significantly compromise these widely held values. In addition, statistical analyses can be plagued with subtle technical flaws that are difficult to detect. When courts face these concerns as well as the problems of remedy discussed in Part II they are understandably hesitant.

I. Moral Responsibility and Free Will. - The requirement of particularity is not surprising in light of common law causation principles,

11 See, e.g., Washington v. Davis, 426 U.S. 229, 238-42 (1976).

12 See McCleskey v. Kemp, 48I U.S. 279, 292 ( 1987 ); see also Allen v. Wright, 468 U.S. 737 , 75 I (1984) (holding that standing requires "personal injury fairly traceable to the [wrongdoer's] allegedly unlawful conduct"); DAVID L. FAIGMAN, Legal AlChEMY: The USE aND Misuse OF SCIENCE IN THE LAW II 7 (1999) (criticizing the McCleskey Court for having introduced this new standard in discrimination cases).

13 E.g., Kennedy, supra note 10, at 1405 (internal quotation marks omitted).

14 See, e.g., Castaneda v. Partida, 430 U.S. 482, 494 (1977) (grand jury); Swann v. CharlotteMecklenburg Bd. of Educ., 402 U.S. I, 24-25 (1971) (school desegregation); see also Daniel R. Ortiz, The Myth of Intent in Equal Protection, 4 I STAN. L. REV. I I05, I I I9-34 (I989) (arguing that in jury selection, voting, and education cases, the intent requirement is significantly attenuated).

15 The Supreme Court typically accepts statistical evidence only when a law's application is so racially disparate that the numbers permit the inference of discriminatory intent. For example, in Gomillion v. Lightfoot, 364 U.S. 339 (1960), the Court found unconstitutional a twenty-eight-sided voting district that redistricted all but four or five of 400 black voters, but no white voters. Id. at 34I; see also Yick Wo v. Hopkins, 1 I 8 U.S. 356, 374 (1886) (finding an equal protection violation when city supervisors denied permits to two hundred Chinese laundries while granting permits to eighty non-Chinese laundries). 
which are binary or mechanistic, ${ }^{16}$ rather than probabilistic. ${ }^{17}$ These principles arise from a Newtonian perspective - every action arises through the will of a free moral actor ${ }^{18}$ - and accord with traditional notions of moral responsibility in the law ${ }^{19}$ and the structure of private law litigation. ${ }^{20}$ Thus, just as tort law requires a plaintiff to show that the defendant more likely than not caused his injury, constitutional law requires a party to show that a government actor's racial animus more likely than not changed the outcome of the case. This understanding of causation creates particularity requirements along two closely related veins: First, the law seeks to blame a specific actor, not societal conditions or the system in general. Second, the law requires that the actor have actually harmed the particular defendant.

The requirement of a particularized wrongdoer manifests itself in the equal protection requirement of purposeful discrimination and in the rejection of statistical proof of harm when a claimant cannot identify a specific wrongdoer. ${ }^{21}$ For example, in McCleskey the Court cited jury uniqueness in denying McCleskey's claim. ${ }^{22}$ Because the jury acted only once, no consistent pattern of racism could be imputed to it. ${ }^{23}$ From the standpoint of individual responsibility, this conclusion makes logical sense - a single point, per se, cannot form a pattern. The systemic result, however, is that discriminatory decisionmakers go undetected, and structural safeguards that could prevent or impede racist decisionmaking are not considered.

The focus on actual harm to the particular defendant bars recovery when statistical studies can demonstrate only a risk of discrimination, not actual discrimination. ${ }^{24}$ This doctrinal rule has normative and practical support. Normatively, denying recovery in the absence of ac-

16 See H.L.A. HART \& TONY HONORE, CaUSATION IN THE LAW 64-7I (2d ed. I985); MORTON J. HORWITZ, THE TRANSFORMATION OF AMERICAN LAW 1870-1960: THE CRISIS OF LEGAL ORTHODOXY 52-57 (1992).

17 Indeed, even if an act or occurrence can be shown to be more probable than not, under traditional causation principles such evidence, standing alone, is insufficient for recovery. See David Rosenberg, The Causal Connection in Mass Exposure Cases: A "Public Law" Vision of the Tort System, 97 HARV. L. REV. 849,857 (1984).

18 See Tribe, supra note 8, at 5-7 (describing Newtonian mechanics).

19 See Abram Chayes, The Role of the Judge in Public Law Litigation, 89 HARV. L. REV. I 281 , 1285 (1976) (noting that intention and fault formed the foundation of the traditional private law system); Rosenberg, supra note 17 , at 858 .

20 See Chayes, supra note 19 , at $1282-83$ (describing private law litigation as bipolar and as involving self-contained episodes confined to discrete parties).

21 Cf. Freeman, supra note 5, at 1052-57 (describing this "perpetrator perspective" that causes courts to "view[] racial discrimination not as a social phenomenon, but merely as the misguided conduct of particular actors").

22 McCleskey v. Kemp, 48I U.S. 279, 294 (1987).

23 See id. at 295 n.r. 5 .

24 See id. at 291 n.7. 
tual harm forgives transgressions in which no evil results" - "no harm, no foul." Practically, compensating every risk that government action imposes would involve enormous transaction costs and measurement difficulties and might well lead to an excessive level of rights enforcement and an overly cautious society. ${ }^{26}$ Every government action theoretically harbors some risk of discrimination; to compensate for all such risks would be unmanageable, if not impossible. ${ }^{27}$

The response to these arguments is two-fold. First, it is possible to distinguish between individual actors and the government. Forgiveness is less normatively appealing when applied to the government, especially because racial discrimination seriously undermines the legitimacy of the criminal justice system. Second, the practical difficulties of compensating all risks do not require courts to compensate no risks. By compensating some subset of "substantial" risks delineated as a matter of policy, the law can avoid the slippery slope. ${ }^{28}$

2. Flawed Statistical Regressions. - From a practical standpoint, courts may be reluctant to open equal protection doctrine to statistical proof for technical reasons. ${ }^{29}$ One of the most significant criticisms of statistical studies on discrimination is the inability of multiple regressions to account for all race-neutral explanations for racial disparities. Statistically, some crimes or behaviors may be more prevalent among members of certain minority groups; thus statistics showing disproportionate sentencing, prosecution, or policing may not reflect any discrimination at all. ${ }^{30}$ Although regressions account for many raceneutral explanations and are thus more sophisticated than the raw numerical comparisons featured in disparate impact arguments, ${ }^{31}$ re-

25 See Rosenberg, supra note 17 , at $882-83$.

26 See ROBERT NOZICK, ANARCHY, STATE, AND UTOPIA 76-77 (1974).

27 These concerns probably underlie the well accepted tort doctrine that one cannot recover for "negligence in the air" (a negligent act that results in no injury). See, e.g., Palsgraf v. Long Island R.R. Co., 162 N.E. 99, 99 (N.Y. 1928) (Cardozo, C.J.). See generally HoRWITZ, supra note 16 , at 56 (discussing the "negligence in the air" doctrine). Similarly, the infeasibility of awarding reversal for any de minimis trial mistake probably underlies the harmless error doctrine.

28 See infra note 79. For a discussion of slippery slopes and the problem of line drawing, see Frederick Schauer, Slippery Slopes, 99 HARV. L. REV. 36 I (1985).

29 The methods by which judges and juries handle statistical and probabilistic evidence would obviously be critical to the successful implementation of a constitutional risk perspective. A general discourse on these issues, however, is beyond the scope of this Note. For a discussion of the advantages of statistical data over experts' judgments, see William Meadow \& Cass R. Sunstein, Statistics, Not Experts (Feb. I , 2000) (unpublished manuscript, on file with the Harvard Law School Library).

30 See United States v. Armstrong, 517 U.S. 456,469 (1996) (implying that different racial groups commit crimes with varying degrees of frequency); $c f$. City of Richmond v. J.A. Croson Co., 488 U.S. 469,507 ( 1989 ) (rejecting the "assumption that minorities will choose a particular trade in lockstep proportion to their representation in the local population").

31 See McCleskey v. Kemp, 48I U.S. 279,327 (1987) (Brennan, J., dissenting) ("Multipleregression analysis is particularly well suited to identify the influence of impermissible considera- 
gressions can never be perfect, and some race-neutral factors may be omitted due to a lack of data. ${ }^{32}$ Historically, courts have cited precisely this possible omission as a reason to disregard statistical showings of racial disparity. ${ }^{33}$

This concern may be valid, but surely parties must do more than speculate about possible flaws to invalidate statistical evidence. The key question is whether the omission of potentially explanatory factors creates sufficient doubt in a study's accuracy to warrant the denial of all relief. Although the omission of variables may affect the probative value of a regression, it should not always render a study entirely inadmissible as evidence of discrimination. ${ }^{34}$ As some statisticians suggest, courts need to consider just how significant a permissible "unknown" factor would have to be to account for the racial disparities

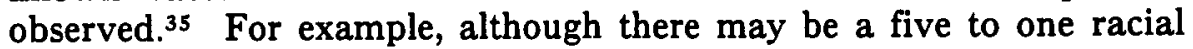
disparity in traffic stops, it is improbable that blacks are five times more likely to speed or to drive with a broken tail light than whites. ${ }^{36}$

The other major problem with using statistical data in the equal protection context is the question of class definition: how one defines one's statistical sample can affect the results of a study. For example, there may be a racial disparity among murder sentences throughout a state, yet there may be no such disparity in a particular county. Courts do, however, face similar problems in mass-tort class actions as

tions in sentencing, since it is able to control for permissible factors that may explain an apparently arbitrary pattern.").

32 See Richard H. McAdams, Race and Selective Prosecution: Discovering the Pitfalls of Armstrong, 73 CHI.-KENT L. REV. 605, 627-33 (1998) (discussing a method to account for correlations between non-racial factors and race and suggesting that collecting data on nonprosecutions is notoriously difficult).

${ }^{33}$ E.g., Armstrong, 5 I 7 U.S. at 470 (citing a lack of evidence regarding "similarly situated persons" of other races); MCCleskey, $48 \mathrm{I}$ U.S. at $295 \mathrm{n} .14$ (distinguishing death penalty cases in which there is "no common standard by which to evaluate all defendants" from jury venire selection cases in which the number of factors is purportedly limited and, "to a great degree, objectively verifiable"); Stephens v. State, 456 S.E.2d 560,562 (Ga. 1995) (finding statistical evidence insufficient and criticizing the potential omission of other race-neutral explanatory factors).

34 Bazemore v. Friday, 478 U.S. 385, 400 (1986) (Brennan, J., concurring in part).

35 See Joseph L. Gastwirth \& Tapan K. Nayak, Statistical Aspects of Cases Concerning Racial Discrimination in Drug Sentencing: Stephens v. State and U.S. v. Armstrong, 87 J. CRIM. L. \& CRIMINOLOGY 583, 590-96 (1997) (suggesting a statistical technique to make this determination). Professor McAdams has made the related suggestion that, when relevant data is unavailable, trial courts should fill in "data gaps" with reasonable assumptions. See McAdams, supra note 32, at 634-40. For example, although numerical data may not exist on the number of nonblack drivers who speed, it is reasonable to assume that at least some do. See id. at 632,637 .

36 But see United States v. Bell, 86 F.3d 820, 823 (8th Cir. I996) (rejecting the defendant's claim of discriminatory enforcement of a bicycle headlamp law because, even if the law was enforced solely against blacks, the defendant failed to show that whites rode bicycles in violation of the statute). 
well as in statutory discrimination actions, which suggests that this difficulty is manageable. ${ }^{37}$

\section{B. Costs}

As already noted, the particularity requirement and its rejection of statistical evidence have substantial costs. The Court's cramped view of constitutional harm forces courts to examine only individual cases, which cannot reveal or redress patterns of racial discrimination. ${ }^{38}$ Considered in isolation, nearly all decisions can be rationalized using permissible explanations; it is only when these decisions are considered in the aggregate that patterns may emerge that indicate the presence of impermissible discrimination. ${ }^{39}$ As a result, the particularity requirement obscures the discriminatory decisions of government actors, making their already broad discretion effectively unreviewable.

It is true that overt discrimination is readily detectable under the traditional particularized harm framework. If a judge overtly relies on race in sentencing defendants to death, or if police departments target motorists because of their race, the discrimination is plain. But the particularized framework, though perhaps effective in past "conquests" 40 of overt discrimination, is wholly inadequate in a contemporary society in which "discrimination takes a form more subtle than before." ${ }^{11}$ Contemporary mores and legal pressures have altered the appearance of racism. Gone are facially discriminatory statutes and prosecution policies. In their place has arisen a racism cloaked in nonracial explanations. ${ }^{42}$ Thus, despite a facially neutral statute and the absence of an overtly discriminatory enforcement policy, regression

37 See, e.g., Md. Troopers Ass'n v. Evans, 993 F.2d 1072, 1077-78 (4th Cir. 1993) (defining the class in a Title VII disparate impact action as the available pool of workers).

38 Cf. Garner v. Jones, I 20 S. Ct. 1362, 1372 \& n. I (2000) (Souter, J., dissenting) (arguing that, in the ex post facto context, a court must examine the effect of a rule change on the class of defendants rather than on the particular defendant because the combination of rules and discretion involved in sentencing precludes ever proving harm in the individual case); JAMES GLEICK, ChaOS: MAKING A NEW SCIENCE 44 (1987) (suggesting that, in the scientific context, looking analytically at individual pieces reveals little about global interactions or changes); Rosenberg, supra note 17 , at $885 \mathrm{n.I4}$ (suggesting that, in the tort context, case-by-case adjudication often overlooks aggregate or systemic problems).

39 Cf. Abram Chayes, The Supreme Court, 198I Term-Foreword: Public Law Litigation and the Burger Court, 96 HARV. L. REV. 4, 39 (1982) (noting that "statistics on employment decisions that by themselves appear neutral or nonprobative may take on a different meaning when seen in the context of the company's overall employment activities").

40 Kennedy, supra note IO, at 1419.

41 Rose v. Mitchell, 443 U.S. 545,559 (1979); id. ("But [the discrimination] is not less real or pernicious."); see Kennedy, supra note Io, at 1419 (discussing how the purposeful discrimination requirement "ignores the chameleonlike ability of prejudice to adapt unobtrusively to new surroundings").

42 See, e.g., LAURENCE H. TRIBE, AMERICAN Constitutional LAW $\S$ 16-20, at i509 (2d ed. 1988) (observing that finding a "bigoted decision-maker" can be difficult). 
analysis may still show that, even after accounting for all relevant nonracial factors, minorities are more likely to be arrested, convicted, or sentenced more harshly. The particularity requirement, however, renders courts incapable of recognizing such risk-based harm.

The broad discretion traditionally afforded government actors in investigating, prosecuting, convicting, and sentencing defendants exacerbates the cloaking phenomenon. ${ }^{43}$ Although some discretion is inevitable because of the resource allocation and complex balancing questions involved,44 broad discretion facilitates the masking of impermissible motives. Together with the judicial deference that usually accompanies it, such discretion fosters an environment acutely susceptible to discrimination..$^{45}$

Moreover, the failure to recognize statistical evidence and constitutional risks of discrimination legitimizes government structures and practices and thereby inhibits not only courts, but also legislatures from examining them. ${ }^{46}$ By denying the existence of discrimination altogether, courts absolve other "governmental and nongovernmental actors of responsibility for solving these problems" through alternative avenues. ${ }^{47}$ The inability to remedy a harm does not justify the refusal to acknowledge its existence. ${ }^{48}$ Finally, because requiring particularized harm will almost always result in a finding of nondiscrimination, courts can theoretically manipulate the required level of particularity to mask ideological preferences for or against greater equal protection. ${ }^{49}$

43 See, e.g., James Vorenberg, Decent Restraint of Prosecutorial Power, 94 HARV. L. REV. I 52 I, I52I-22 (I98I) (discussing how prosecutors have gained discretion while other actors such as magistrates, parole boards, and correctional officials have been constrained); infra note I 15 .

44 Wayte v. United States, 470 U.S. 598, 607 (1985) (suggesting that prosecutorial discretion is necessary because of resource limitations and because of the "systemic costs" of judicial supervision, which include chilling law enforcement by scrutinizing prosecutorial motives and undermining prosecutorial effectiveness by "revealing the Government's enforcement policy").

45 See infra note 110.

46 See Kennedy, supra note 10 , at 1416.

47 Tribe, supra note 8, at 34 ; see id. at 33-34 (criticizing McCleskey on this ground); $c f$. id. at 30 (arguing that, in a school desegregation case, even if the Court "would have had no impact on judicial remedies, a judicial proclamation that inner city ghettoization was constitutionally infirm might have avoided legitimating this nationwide travesty").

48 See id. at 38 (explaining that modernism teaches that "we can see more than we can $d o$," but that "this does not mean that we should lie about what we see").

49 Cf. Allen v. Wright, 468 U.S. 737,767 (1984) (Brennan, J., dissenting) (accusing the Court of manipulating standing to disguise a decision on the merits); Dan M. Kahan, The Secret Ambition of Deterrence, I I 3 HARV. L. REV. 41 3, 428-35 (I999) (describing the use of deterrence-based arguments as a rhetorical strategy to pacify debates and to mask ideological preferences).

This observation does not mean that courts regularly use doctrinal manipulations to achieve desired substantive outcomes, but the threat that courts might do so nonetheless exists. For example, a skeptical observer of ex post facto doctrine could suggest that the Court has manipulated the required level of particularity to make relief more difficult to obtain: when particularized harm is easier to prove, the Court requires general systemic harm; when general systemic harm is 


\section{Effects}

A brief survey of equal protection doctrine in sentencing, prosecution, and policing evinces the pervasive culture of particularity and its consequences. Courts have generally declined to award relief on the basis of statistical racial disparities, focusing instead on the particular facts of each case.

I. Sentencing. - Despite various studies showing racial disparities in sentencing, ${ }^{50}$ the bottom line is simple: no court has ever found an equal protection violation on the basis of racial disparities. ${ }^{51}$ Although the reasons for this stark result are complex, the principal decisions leave little doubt that the particularity requirement has played a critical role. For example, in $\mathrm{McCleskey}$, although the Court assumed the validity of the statistical studies arguendo ${ }^{52}$ - thus allowing the discussion to venture beyond surface-level empirical debates - it still denied relief, focusing on the particulars of McCleskey's case. According to the Court, McCleskey could not claim discrimination because he was indeed guilty as charged - he had "committed an act for which the United States Constitution and Georgia laws permit imposition of the death penalty." 53 Furthermore, the Court emphasized that the corollary of the purposeful discrimination requirement of Washington

easier to prove, the Court requires particularized harm. Compare Seling v. Young, 2 I S. Ct. 727 , 734-35 (2001) (requiring that "punitiveness" for ex post facto purposes be determined facially that is, systemically - and finding that the defendant's particularized showing was insufficient), with Garner v. Jones, I20 S. Ct. 1362, 1370 (2000) (requiring a claimant to "show that as applied to his own sentence the law created a significant risk of increasing his punishment ${ }^{\prime}$ ).

so See generally David C. Baldus, George Woodworth, David Zuckerman, Neil Alan Weiner \& Barbara Broffitt, Racial Discrimination and the Death Penalty in the Post-Furman Era: An Empirical and Legal Overview, with Recent Findings from Philadelphia, 83 CORNELL L. REV. 1638, I658-62 (1998) (citing U.S. GeN. ACCOUNTING OFfICE, DeATH PeNalty Sentencing: RESEARCH INDICATES PATTERN OF RACIAL DISPARITIES (I990), which surveyed twentyeight statistical studies and found strong evidence of race-of-the-victim discrimination but equivocal evidence of race-of-the-defendant discrimination); id. at 1676-1710 (discussing capital sentencing disparities in Philadelphia from 1983 to 1993).

51 See Kennedy, supra note 10, at 1402 ("[A]s far as reported cases disclose, no defendant in state or federal court has ever successfully challenged his punishment on grounds of racial discrimination in sentencing." (emphasis omitted)).

52 McCleskey v. Kemp, 48I U.S. 279, 291 n.7 (1987). The empirical validity of racial disparities in sentencing has been a matter of ongoing controversy, but suspicions of racial discrimination in capital sentencing are not new. In Furman v. Georgia, 408 U.S. 238 (1972), several Justices, including the dissenting Chief Justice Burger, all expressed concerns about racial discrimination in capital cases. See id. at 257 (Douglas, J., concurring) (blaming standardless statutes for the discriminatory imposition of the death penalty); id. at 310 (Stewart, J., concurring) (" $[I] f$ any basis can be discerned for the selection of these few to be sentenced to die, it is the constitutionally impermissible basis of race."); id. at 364 (Marshall, J., concurring) (stating that, "while the higher rate of execution among [blacks] is partially due to a higher rate of crime, there is evidence of discrimination"); id. at 389 n.1 2 (Burger, C.J., dissenting) (acknowledging disparities).

53 McCleskey, 48 I U.S. at 297. 
v. Davis ${ }^{54}$ was that "a criminal defendant must prove that the purposeful discrimination 'had a discriminatory effect' on him."55 McCleskey had "offer[ed] no evidence specific to his own case that would support an inference that racial considerations played a part in his sentence,"56 and thus was not entitled to relief.

The $M c$ Cleskey Court thus manifested a legal consciousness narrowly focused on particular acts. The statistical studies showing racial disparities in sentencing were discarded as irrelevant to the individualized determination of justice. ${ }^{57}$ Even more telling was the Court's revealing statement in a footnote that "[e]ven a sophisticated multipleregression analysis ... can only demonstrate a risk that the factor of race entered into some capital sentencing decisions and a necessarily lesser risk that race entered into any particular sentencing decision." 58 In other words, the risk of racial discrimination, in and of itself, was simply not enough.

Defendants claiming racial disparities in noncapital sentencing have fared no better. ${ }^{59}$ After all, if the gravity of capital punishment

54426 U.S. 229 ( 1976 ) (requiring discriminatory intent for equal protection claims).

55 McCleskey, 48I U.S. at 292 (emphasis added) (citations omitted) (quoting Wayte v. United States, 470 U.S. $598,608(1985)$ ).

56 Id. at $292-93$.

57 Lower courts' treatment of racial disparities in capital sentences for rape prior to Coker $v$. Georgia, 433 U.S. 584 (1977), which abolished the death penalty for rape, further demonstrates the legal culture of particularity. See, e.g., Maxwell v. Bishop, 398 F.2d 138, 146-47 (8th Cir. 1968) (Blackmun, J.) (focusing on the aggravating factors in the particular case and downplaying statistical disparities); State v. Mayo, 87 So. 2d 50r, 503 (Fla. 1956) (denying relief despite statistics showing that over a twenty-year period only one white man but twenty-three black men were sentenced to death for rape). See generally Marvin E. Wolfgang \& Marc Riedel, Rape, Racial Discrimination and the Death Penalty, in CAPITAL PUnishment in THE UNITEd STATES 99, 107-18 (Hugo Adam Bedau \& Chester M. Pierce eds., 1976) (discussing empirical findings of racial disparities in capital rape sentencing from $I 945$ to $I 965$ ).

Despite the culture of particularity, the disturbing ramifications of statistical studies became increasingly apparent to jurists in the early rg6os. See Arthur J. Goldberg, Memorandum to the Conference: Re: Capital Punishment, October Term I963, 27 S. TEX. L. REV. 493, 504 n.1 7 (1986); see also Michael Meltsner, CRUel and UnUSUAL: The SUPREME CoURT AND CAPITAL PUNISHMENT 28-29 (1973). In fact, although Coker was ultimately decided on Eighth Amendment grounds and did not address racial concerns, such considerations were clearly in the background. See McCleskey, 481 U.S. at 332 (Brennan, J., dissenting) ("Although the [Coker] Court did not explicitly mention race, the decision had to have been informed by the specific observations on rape by both the Chief Justice and Justice Powell in Furman.").

58 McCleskey, 48 I U.S. at 291 n.7.

59 See, e.g., Stephens v. State, 456 S.E.2d 560, 562 (Ga. I995) (discounting racial disparities among prosecutorial requests for life sentences for repeat drug offenders due to the potential presence of other permissible explanatory factors). See generally Developments in the Law-Race and the Criminal Process, IOI HARV. L. REV. 1472, I630-35 (1987) [hereinafter Developments] (tying disparities in noncapital sentencing to discriminatory parole board decisions). A well-known controversy about racial disparities in noncapital sentencing involves the Sentencing Guidelines' treatment of crack versus powder cocaine. David A. Sklansky, Cocaine, Race, and Equal Protection, 47 STAN. L. REV. 1283 (1995). The crack/powder cocaine issue, however, is different from the one addressed in this Note. This Note addresses racial disparities that remain after regression 
has not moved courts to consider statistical evidence, why would noncapital sentencing? Courts have predictably relied on the particularity requirement to deny discrimination claims, focusing especially on remedial difficulties. ${ }^{60}$ As Judge Clark acknowledged in the lower court's consideration of $M c$ Cleskey, even if racial bias randomly arose in twenty percent of all convictions, judges could not simply overturn them all. ${ }^{61}$ Without a direct showing of discrimination in a specific case, little could be done. ${ }^{62}$

2. Prosecution. - As in the sentencing context, defendants have rarely, if ever, brought successful claims for racially discriminatory prosecution. ${ }^{63}$ Indeed, defendants have rarely succeeded in making any selective prosecution claim at all. ${ }^{64}$ In denying relief, courts have focused less on a particular defendant's acts (as in the sentencing context) and more on the defendant's inability to show that prosecutors purposefully caused the racial disparities. ${ }^{65}$ Only when the statistical disparities have been outrageous enough to make purposeful discrimination a virtual certainty have courts granted relief.

For example, in the only recent Supreme Court case dealing with alleged racially discriminatory prosecution, United States $v$. Armstrong, ${ }^{66}$ the defendant argued that black crack-cocaine offenders were

accounts for possible race-neutral factors, while the other inquiry focuses on a disparate impact argument that disregards whether race may be merely correlated with a particular race-neutral trait (for example, crack cocaine use).

60 See infra Part II.

61 McCleskey v. Kemp, 753 F.2d 877, 927 (I Ith Cir. I985) (en banc) (Clark, J., dissenting in part and concurring in part) ("The societal imperative of maintaining a criminal justice system ... would outweigh the mandate that race or other prejudice not infiltrate the legal process."). Judge Clark's dissent, however, distinguished capital sentencing, in which any racial discrimination was impermissible, from noncapital sentencing, which was subject to this pragmatic consideration. See id.

62 See id.

63 See Randall Kennedy, Race, CRime, AND The LaW 354 n.* (r 997 ) (arguing that no American court has ever found a prosecutor to have engaged in racially selective prosecution). Concededly, besides the one in Armstrong, statistical studies for discriminatory prosecution have thus far been relatively unsophisticated and episodic. See, e.g., U.S. v. Figueroa-Rocha, No. CR94-20103-JW, I 995 WL 253050, at *3 (N.D. Cal. April 27, 1995) (addressing raw numerical disparities in the enforcement of an immigration law); see also Angela J. Davis, Prosecution and Race: The Power and Privilege of Discretion, 67 FORDHAM L. REV. 13, 55-56 (1998) (implying that a rigorous statistical study would be necessary for credible evaluation of prosecutorial practices). Given the high cost of such studies and the Court's unwillingness to rely on them even in death penalty cases, such a result is unsurprising.

64 See McAdams, supra note 32 , at 616 n.55.

65 See, e.g.,.Butler v. Cooper, 554 F.2d 645, 647 (4th Cir. 1977) (denying relief despite studies showing that eighty-four percent of persons arrested for violating liquor laws were black in a county with only a thirty-three percent black population). But cf. State v. Kennedy, 588 A.2d 834, 840-4I (N.J. Super. Ct. App. Div. I991) (allowing statistical disparities to establish a colorable claim of discrimination and thus permitting discovery).

66 517 U.S. 456 (1996). 
disproportionately tried under harsher federal laws. ${ }^{67}$ Statistics revealed that every one of the twenty-four federal crack cocaine cases tried by the local federal defenders office involved black defendants, and affidavits suggested that white offenders had been tried only in state court, in which penalties were considerably lighter. ${ }^{68}$ Based on this evidence, the district court granted the defendant discovery of the prosecution's records. The Supreme Court reversed, holding that the evidence failed to show that "similarly situated individuals of a different race were not prosecuted," 69 and thus that the evidence was insufficient to warrant discovery. ${ }^{70}$

3. Policing. - Even if explicit racial profiling were to be found unconstitutional, ${ }^{71}$ similar doctrinal problems would hinder redress of discriminatory police practices. For example, studies report that a disproportionate number of minority motorists are pulled over while acting no differently than their white counterparts. ${ }^{72}$ Despite the danger of facilitating this practice, the Court in Whren $v$. United States ${ }^{73}$ nonetheless validated pretextual stops and searches of cars under the Fourth Amendment. ${ }^{74}$ In addition, under City of Los Angeles v. Ly$o n s,{ }^{75}$ to obtain an injunction against a discriminatory police practice, a plaintiff must show a high likelihood that he in particular will be injured again. ${ }^{76}$ Thus, the particularity requirement once again presents a sizeable obstacle to relief for targeted groups.

67 Id. at $458-59$.

68 Id. at $459-6 \mathrm{I}$.

$69 \mathrm{Id}$. at 465 .

70 Id. at 470 .

71 Racial profiling remains a controversial issue, and a number of commentators deny its constitutionality. See Pamela S. Karlan, Race, Rights, and Remedies in Criminal Adjudication, 96 MICH. L. REV. 200I, 2006-07 (1998) (suggesting that the use by many police departments of statistical profiles in which race is a factor is likely unconstitutional). The difficulty of determining the constitutionality of racial profiling is closely linked to the difficulty posed by disparate impact theories. See supra p. 2 I03. To the extent that certain minority groups may on average commit a greater percentage of certain crimes, profiling is strictly speaking "rational," but other societal values may make such stereotyping impermissible or undesirable. Cf. Powers v. Ohio, 499 U.S. 400,410 (I99I) (rejecting the use of race as a proxy for bias in the peremptory challenge context). See generally KENNEDY, supra note 63 , at $1_{36-67}$ (discussing the rationality, but undesirability, of using race as a proxy).

72 See David A. Harris, "Driving While Black" and All Other Traffic Offenses: The Supreme Court and Pretextual Traffic Stops, 87 J. CRIM. L. \& CRIMINology 544, 56 I-69 (I997) (detailing studies in Florida, Maryland, Illinois, and Colorado).

73517 U.S. 806 (1996).

$74 \mathrm{See} i d$. at 8I0, 813 (acknowledging the danger of racially discriminatory pretextual searches but holding that the applicable provision is the Equal Protection Clause, not the Fourth Amendment).

7546 I U.S. $95\left(\mathrm{I}_{98}\right)$

76 Id. at 105-06; see also id. at I I I-1 2 (cautioning judicial restraint when interfering with state law enforcement in the absence of a substantial risk of irreparable injury). The Court has applied 


\section{CoNStitutional RISK AND THE REMEDY PROBLEM}

The shortcomings of the traditional particularized harm requirement can be ameliorated by a greater focus on and acknowledgment of constitutional risks. Drawing from the mass tort context, this shift can be achieved in two ways: Rather than viewing risk as an irremediable possibility of harm, one can view risk as a remediable harm in itself." Or, one may presume that, given a large enough population, what is traditionally "only" a risk is statistically certain to materialize into an "actual" harm: ${ }^{78}$ yet because the actual manifestation of harm may be difficult to locate, one may prefer to empower third parties or private attorneys general for enforcement purposes.

These alternatives are essentially two sides of the same coin, but this Note pursues only the first. ${ }^{79}$ Seeing risk as a remediable harm in itself fits well with the current individualistic conception of causation. In addition, by characterizing risk as injury in fact, one can address constitutional risks while avoiding doctrinal standing obstacles. ${ }^{80}$

Conceptualizing constitutional risks as remediable harms would address the racial disparity concerns raised in section I.C. ${ }^{81}$ Greater acceptance of statistical evidence would better enable courts to see potential patterns of discrimination and to assess whether certain aspects of the criminal process are structured appropriately to minimize dis-

similar principles to discriminatory prosecution. See O'Shea v. Littleton, 4I4 U.S. 488, 495-99 (r974).

${ }_{77}$ See Herskovits v. Group Health Coop. of Puget Sound, 664 P.2d 474, 481, 485-86 (Wash. 1983) (Pearson, J., concurring); see also NOZICK, supra note 26 , at $75-77$ (discussing various methods of compensating risk); $(f$. Joseph H. King, Jr., Causation, Valuation, and Chance in Personal Injury Torts Involving Preexisting Conditions and Future Consequences, 9o YALE L.J. 1353,1364 (1981) (advocating "[a] more rational approach ... [that] would allow recovery for the loss of the chance of cure even though the chance was not better than even").

78 See Rosenberg, supra note 17 , at 884-87; of. John Fabian Witt, Toward a New History of American Accident Law: Classical Tort Law and the Cooperative First-Party Insurance Movement, I 4 HARV. L. REV. 690, 701 $0_{4}$ (200I) (recounting the changes in the law of unintentional torts that resulted from statistically inevitable industrial accidents).

79 By conceiving of risks as harms, the law must, as a practical matter, deal only with "substantial" risks to prevent an explosion of claims. See Herskovits, $66_{4}$ P.2d at 476 (suggesting that courts may need to limit recovery to "significant" risks). The line between "de minimis" risks and "substantial" risks is drawn as a matter of policy, just like the one delimiting "proximate" cause. See Palsgraf v. Long Island R.R. Co., I62 N.E. 99, 103 (N.Y. 1928) (Cardozo, C.J.); NozICK, supra note 26 , at $76-77$ \& n.*.

80 See Cass R. Sunstein, Standing and the Privatization of Public Law, 88 ColUM. L. Rev. 1432, 1464-66 (1988) (explaining why the question of standing rests substantially on the characterization of the relevant injury).

81 On a theoretical level, the systemic and aggregative approach of a constitutional risk perspective may also be more consistent with equal protection than is the particularity approach. Although the battle against racism has perhaps traditionally had a more individualistic tone, emphasizing each person as an individual and not as a stereotype, the concept of equal protection itself invites comparisons on a systemwide basis. It invites comparisons among sentences, prosecutions, and traffic stops. It invites an examination of whether justice is equally distributed. 
crimination. At a minimum, a constitutional risk perspective would ensure that courts recognize the problem of discrimination in the criminal justice system. ${ }^{82}$ Even if an effective court-imposed remedy were unavailable, acceptance of statistical evidence in the courts would impress the problem of discrimination on both government actors and the public at large.

Ideally, however, constitutional rights should be enforceable by adequate remedies. ${ }^{83}$ Thus, the principal difficulty with achieving judicial acceptance of the constitutional risk perspective will be finding effective but appropriately cabined remedies. ${ }^{84}$ As the remainder of this Part demonstrates, the traditional remedy for constitutional violations (reversal or dismissal) seems ill suited to address constitutional risks, as does the more activist remedy of a structural injunction. The solution rests instead with tweaking the equal protection right itself to create a requirement of procedural safeguards.

\section{A. Sanctions}

I. Dismissal. - Dismissal or reversal ${ }^{85}$ has ordinarily been the remedy used to redress constitutional violations in the criminal process. $^{86}$ A substantial problem with dismissal remedies, however, is the oft-heard complaint that they are windfalls to defendants. ${ }^{87}$ Defendants are freed not because they are innocent, but rather because of some problem in the criminal system itself. For this reason, although equal protection challenges in the criminal law context are perhaps more in need of redress for reasons of legitimacy and justice, they are more difficult to vindicate than those in other contexts. Unlike in other contexts, in which claimants are at least occasionally sympathetic, in the criminal context the claimant is nearly always a con-

82 Acknowledging constitutional risks will invariably require greater use and acceptance of statistics, and therefore courts may have to develop greater familiarity with and expertise in this area. As in other fields, however, the use of statistics and probability should be unremarkable. In the natural sciences, scientists often resort to statistics and probability to describe the physical world when a system becomes too complex to model using cause and effect relationships. Described by some as a "mathematical theory of ignorance," when one cannot follow the behavior of every particle or actor in a system, science settles for describing it holistically through the use of statistics. See MORRIS KLINE, MATHEMATICS IN WESTERN CULTURE 340-58 (I953).

83 See Marbury v. Madison, 5 U.S. (I Cranch) I37, I66 (1803).

84 See Karlan, supra note 71 , at 2029 (suggesting that the problems regarding equal protection and the criminal justice system are "as much about remedies as about rights").

85 Reversal remedies, however, are inappropriate for constitutional risks because the harm involved is systemic and therefore will persist even in a retrial.

86 See, e.g., McCleskey v. Kemp, 481 U.S. 279,348 (I987) (Blackmun, J., dissenting). But see United States v. Armstrong, 5 I 7 U.S. 456, $46 \mathrm{I}$ n.2 (I996) (noting that the Court has not yet ruled on the appropriate remedy for discriminatory prosecution).

87 See, e.g., Akhil Reed Amar, Sixth Amendment First Principles, 84 GEO. L.J. 64I, 646 (1996). 
victed defendant. Courts therefore unsurprisingly tend to narrow the circumstances under which a defendant can obtain a reversal. ${ }^{88}$

Some might argue that the importance of vindicating equal protection rights in the criminal justice system justifies the social costs of releasing or retrying guilty defendants. Because defendants have the greatest incentive to monitor the system, they are needed as private attorneys general to deter state actors from unconstitutional behavior. ${ }^{89}$ Nevertheless, the suitability of a private-attorney-general system in the constitutional risk context does not necessarily follow from its acceptance in the traditional context of proven, particularized discrimination. The right-remedy gap is even more pronounced when the harms suffered are constitutional risks - traditional harms discounted by probability. If dismissal for racially motivated prosecution of an otherwise guilty bank robber is already disproportionate, then dismissal when there was only a risk of racially motivated prosecution is even more problematic.

Constitutional risk presents an even more serious problem for dismissal remedies. Unlike the traditional particularized harm regime, a constitutional risk regime cannot limit dismissal to a small class of defendants. Because constitutional risk acknowledges a systemic problem, it would make dismissals available to all future defendants, calling into question the entire criminal justice system..$^{90}$ This kind of wide-ranging reductio argument weighed heavily in $M c$ Cleskey. ${ }^{91}$

2. Rebuttable Presumptions. - One solution to the dismissal problem would be to allow constitutional risks to create a rebuttable presumption of constitutional infirmity. ${ }^{92}$ When a defendant demon-

88 See Karlan, stupra note $7 \mathrm{I}$, at 2005 (suggesting that concerns about the dismissal remedy led the Court to use the intent standard to eviscerate equal protection doctrine in the area of selective prosecution).

89 For a general discussion on the usefulness of granting windfalls to private attorneys general to enforce constitutional provisions, see Daniel J. Meltzer, Deterring Constitutional Violations by Law Enforcement Officials: Plaintiffs and Defendants as Private Attomeys General, 88 COLUM. L. REV. 247 (1988).

$90 \mathrm{Cf}$. Rhodes v. Chapman, 452 U.S. 337,367 n.I 5 (198I) (Brennan, J., concurring) (acknowledging that if "less than $6_{3}$ square feet of cell space per inmate were a per se violation of the Eighth Amendment, then approximately two-thirds of all federal, state and local inmates today would be unconstitutionally confined").

91 See McCleskey, 48 I U.S. at 293 (expressing concern that McCleskey's claim "would extend to all capital cases in Georgia, at least where the victim was white and the defendant [was] black"); id. at 314-IS (expressing concern that McCleskey's capital sentencing claim could easily be extended to all other types of penalty); see also McCleskey v. Kemp, 753 F.2d 877,927 (I Ith Cir. I985) (Clark, J., dissenting) (acknowledging that even if racial bias randomly arose in twenty percent of noncapital convictions, federal courts could not realistically strike down all prosecutions).

92 In the aftermath of $M c$ Cleskey, Congress considered allowing statistical proof to establish such a presumption in capital sentencing cases, but the bill ultimately failed. See Racial Justice Act of 1989 , S. I696, Iorst Cong. $\$ 2922(\mathrm{~b})(\mathrm{r})(\mathrm{r} 989)$; $c f$. KY. REV. STAT. ANN. $\$ 532.300(3)$, (5) 
strates an otherwise inexplicable racial disparity, a constitutional violation would be presumed unless the government could produce a neutral explanation for its behavior. Such presumptions have often been used in the jury selection and school segregation contexts. ${ }^{93}$ Critics may argue, however, that such rebuttable presumptions create costly burdens on law enforcement and prosecutors given their limited resources, especially if the collection of statistical and other data justifying racial disparities is costly and difficult.

In addition, a rebuttable presumption still presupposes the existence of a particularized wrongdoer who can provide a race-neutral explanation. In the criminal justice system, such explanations are often unavailable. For example, jury deliberations are strictly confidential, making an allegation of racial discrimination impossible to rebut. In these instances, the rebuttable presumption would be no different than dismissal.

On the flip side, small sample sizes make race-neutral explanations impossible to refute. Even if juries had open deliberations, they still convict and sentence only once, and individual prosecutors try few cases with similar factual situations. In such circumstances, these actors can easily rationalize potentially discriminatory conduct by giving race-neutral explanations. ${ }^{94}$ Rebuttable presumptions would therefore fail to remedy the constitutional risk.

3. Discovery. - Another alternative would be to grant discovery requests by defendants who raise plausible statistical claims, but to leave the burden of proof on them. "[M]ost of the relevant proof in selective prosecution cases will normally be in the Government's hands," 95 so discovery will provide additional data for defendants seeking to satisfy the traditional requirement of discriminatory purpose. Armstrong, of course, rejected precisely this discovery remedy, ${ }^{96}$ but that decision arguably rested on the Court's particularized view of harm: because Armstrong had proven no harm in his particular case,

(Michie I999) (allowing a defendant to use statistics to prove racial discrimination by clear and convincing evidence).

93 E.g., Batson v. Kentucky, 476 U.S. 79, 96-98 (I 986) (peremptory challenges); Swann v. Charlotte-Mecklenburg Bd. of Educ., 402 U.S. I, 26 (I97I) (previously segregated school district); see Sklansky, supra note 59 , at 1318 .

94 This problem is one of the reasons that the rule against race-based peremptory challenges under Batson has essentially been eviscerated. See, e.g., United States v. Lorenzo, 995 F.2d 1448, 1454-55 (9th Cir. 1993) (permitting peremptory challenges to three potential jurors with Hawaiian surnames for race-neutral reasons such as lack of attentiveness, financial hardship, and having long hair and a beard); see also Karlan, supra note 71, at 202I \& nn.96-10I (reporting explanations such as weight, handwriting, clothing, and attitude).

95 Wayte v. United States, 470 U.S. 598, 624 (Marshall, J., dissenting).

96 United States v. Armstrong, 5 77 U.S. 456, 465 (1996) (rejecting discovery for, inter alia, its possible chilling effect on law enforcement and its potential to reveal the government's enforcement policy). 
he was not entitled to discovery. Were the Court to recognize constitutional risk as an actual harm, one could imagine the Court being more inclined to grant a discovery "sanction."97

Although granting discovery on the basis of constitutional risk would be an improvement over the present Armstrong doctrine, discovery too suffers from reliance on particularized wrongdoers. Discovery is only useful to defendants if the information discovered can prove intent, but short of finding the proverbial "smoking gun," discovery will likely provide only more statistical data, and little will be gained. And as precedent suggests, only in extreme cases will courts infer intent solely from statistical disparities. ${ }^{98}$

4. Proportional Remedies. - Within the realm of compensatory remedies, constitutional risk faces a dilemma. On the one hand, it is unclear what remedy other than dismissal or a sentence reduction would provide sufficient incentive for a defendant "to ferret out racial discrimination." remedy for constitutional risk. Constitutional risk varies by degrees the harm inflicted depends on the magnitude of the risk. Dismissal, however, is a binary remedy - either a defendant escapes conviction or he does not. Dismissal is thus a windfall because it cannot be discounted to fit varying levels of harm.

This mismatch between harm and remedy exists at most stages of the criminal process: decisions to prosecute, convict, or sentence to death are all binary. But at some stages, such as noncapital sentencing, differences of degree do exist, theoretically allowing courts to discount for uncertainty. As in the tort context, courts could discount what would otherwise be full compensation by awarding proportional remedies. ${ }^{100}$ More specifically, if a statistical study (having sufficiently accounted for all nonracial explanatory factors) were to demonstrate

97 Cf. McAdams, supra note 32, at 658 (arguing that discovery is a useful sanction because it is costly to prosecutors and is an intermediate remedy); Anne Bowen Poulin, Prosecutorial Discretion and Selective Prosecution, 34 AM. CRIM. L. REV. 1071, 1090-98 (1997) (arguing for discovery as a form of "soft enforcement"). However, although discovery may impose costs on government actors and deter unconstitutional conduct, it is not a "true" sanction. Unless a reasonable opportunity for ultimate dismissal accompanies discovery, defendants will lack the adequate incentives to bring claims.

98 See supra note 15.

99 Karlan, supra note $7 \mathrm{I}$, at 2028 . Civil damages, the common law remedy for rights violations, seem unhelpful to defendants facing death or incarceration, and defendants also face barriers such as prosecutorial immunity, see Imbler v. Pachtman, 424 U.S. 409, 43 I (I976), and unsympathetic juries, see Karlan, supra note $7 \mathrm{I}$, at 2012.

100 Professor William J. Stuntz suggested this insight in private conversation. $C f$. Herskovits v. Group Health Coop. of Puget Sound, $66_{4}$ P.2d 474, 487 (Wash. I983) (Pearson, J., concurring) (suggesting a discount of full compensatory damages to reflect the level of risk imposed by the wrongdoer); Rosenberg, supra note I7, at 867 (same). For a related discussion in the context of verdicts, see Michael Abramowicz, A Compromise Approach to Compromise Verdicts, 89 CAL. L. REV. 23 I (2001). 
that the average black defendant received a twenty-five percent greater prison sentence for a particular crime than did the average white defendant, then courts could simply reduce a black defendant's sentence by twenty-five percent. Because all black defendants could prove this risk, they would all receive the twenty-five percent reduction. No overdeterrence or windfall would result, ${ }^{101}$ and the compensation would be directly proportional to the imposed risk. ${ }^{102}$ Courts might therefore be more amenable to granting proportional relief for claims of constitutional risk.

Despite the possible benefits of a proportional remedy, this alternative suffers from a number of significant difficulties, the most obvious of which is that it amounts to a race-based remedy. Only defendants of the race at risk would receive reduced sentences, a situation that raises grave political and equal protection concerns. ${ }^{103}$ Another serious problem is that proportional remedies may undermine public acceptance of court decisions. ${ }^{104}$ Observers could find the remedy strange and the message ambiguous: courts would recognize the existence of racial discrimination, but rather than develop doctrines to deter or stop equal protection violations, they would merely cut the baby in half.

\section{B. Structural Injunctions}

One might view the mismatch between dismissal and constitutional risk as the predictable result of applying old fixes to new contexts. The constitutional risk perspective addresses systemic, not particularized harm. So although a traditional remedy may be preferable to advocates of judicial restraint, a more systemic remedy may be necessary.

If the goal is systemic change, then structural injunctions seemingly provide a ready answer. If the system creates constitutional risk, then why not require changes in the system? Rather than take the circuitous route of granting windfalls to guilty defendants to deter government discrimination and to eliminate racial disparities, courts could simply mandate an end to inexplicable racial disparities. ${ }^{105}$ For exam-

101 Prosecutors could not overcharge minority defendants to compensate for the sentencing discount, because such overcharging would itself theoretically exacerbate racial disparities that would justify greater proportional compensation in the future.

102 See Rosenberg, supra note $\mathrm{I} 7$, at $88 \mathrm{I}-85$.

103 See Md. Troopers Ass'n v. Evans, 993 F.2d 1072, 1076 (4th Cir. 1993) (stating that courts should employ race-based remedies only as a "last-resort" because "the use of race as a reparational device risks perpetuating the very race-consciousness such a remedy purports to overcome").

104 Cf. Charles Nesson, The Evidence or the Event? On Judicial Proof and the Acceptability of Verdicts, 98 HARV. L. REV. I357, 1382-84 (1985) (explaining how "proportionate awards" may undermine attempts to shape behavior).

105 Cf. Chayes, supre note 19 , at 1292-96 (noting the rise of injunctions and other equitable relief in public law litigation). 
ple, an injunction could require the ratcheting up of arrests and prosecutions of whites until the disparities disappeared. ${ }^{106}$

A structural remedy, however, faces substantial obstacles. First, injunctions cannot realistically address jury discrimination because juries are one-time actors and because direct interference with their deliberations would raise Sixth Amendment concerns. ${ }^{107}$ Second, unlike injunctions in the prison or school context, injunctions forcing increased prosecutions provide no benefit, and therefore no incentive, to defendants. ${ }^{108}$ Third, as a race-based remedy, a "ratchet-up" injunction would itself raise equal protection problems. In fact, it would be far worse than proportional remedies because government actors would explicitly use race to target individuals for prosecution. ${ }^{109}$

\section{Discretionary Guidelines}

Remedies can be arranged along a spectrum of increasing judicial activism. At one end, sanctions, representing more passive remedies, use deterrence to influence other branches of government indirectly. At the other end, structural injunctions are far more active and impose judicially desired results directly. Both have significant drawbacks in combating constitutional risks, leading one to search for a middleground solution that would address structural defects with minimal intrusiveness. A possible compromise would have courts sanction the government not for imposing constitutional risks, but for failing to minimize them through structural safeguards.

106 Courts could also use a "ratchet-up" injunction to address race-of-the-victim discrimination. See Kennedy, supra note 10, at $1390-91$.

107 Cf. Carol S. Steiker \& Jordan M. Steiker, Sober Second Thoughts: Reflections on Two Decades of Constitutional Regulation of Capital Punishment, IOg HARV. L. REV. 355, 420 (1995) (arguing that a "ratchet-up" is unavailable to enforce equality in capital sentencing because courts cannot compel decisionmakers to impose that penalty).

108 Presumably, interest groups could take up the mantle, but only if they successfully overcame third-party standing obstacles.

109 Structural injunctions also implicate concerns about judicial intrusiveness, which often explain the great reluctance of courts to impose them. See, e.g., Robert A. Burt, Disorder in the Court: The Death Penalty and the Constitution, 85 MICH. L. REV. I 74I, I 797-98 (1987) (discussing the $\mathrm{McCleskey}$ Court's reluctance to undertake a "wholesale restructuring" of the system); see also TRIBE, supra note $42, \S 16-20$, at 1510 (suggesting that the Court's use of the discriminatory intent standard in equal protection cases stems from a "trepidation about embracing the highly intrusive structural remedies that may be required to root out the entrenched results of racial subjugation"). By interfering with prosecutorial decisions, the judiciary meddles in a traditionally exclusive province of the executive branch, see, e.g., Bordenkircher v. Hayes, 434 U.S. 357,364 (1978), and an area in which it is institutionally ill suited to make decisions, see, e.g., Wayte v. United States, 470 U.S. 598,607 (1985). Sentencing may be a more appropriate area for judicial intervention. See Sklansky, supra note 59, at 1316 (arguing that criminal sentencing is "close to the core" of the judiciary's competence). But even in the sentencing context it is unclear whether appellate courts are well suited to such fact-based inquiries. 
I. Reining In Discretion. - Discretion is often at the root of discrimination. ${ }^{110}$ Theoretically, given a facially race-neutral statute, no discrimination could occur if government actors had an obligation to arrest, prosecute, and sentence everyone in exactly the same way. Discretion, however, is inevitable in practice: rules have gaps; ${ }^{111}$ discretion is often desirable in contexts such as sentencing that involve complex judgment calls; $;^{12}$ and broad criminal statutes coupled with limited resources make the prosecution of all crimes impossible. ${ }^{113}$ But the fact that discretion is inevitable does not mean that it must be unbridled. Courts and legislatures can restrain discretion with guidelines and record-keeping requirements that reduce the risk of discrimination. ${ }^{114}$

The existence of an unexplained racial disparity - a constitutional risk - suggests that the criminal justice system may be according government actors too much discretion. If one accepts this assertion, then the racial disparities discussed in section I.C should come as little surprise. Law enforcement, prosecutorial, and sentencing decisions are generally governed by few guidelines ${ }^{115}$ and are often accompanied by little or no record of their decisionmaking processes. Without records or standards, appellate courts lack the tools for meaningful review of discretion; such a scenario, in turn, opens the door to latent discrimination.

2. Guidelines and Record-keeping. - The above observation suggests a modification of equal protection doctrine in the context of con-

110 See Kenneth Culp Davis, Discretionary Justice: A Preliminary Inquiry I70 (Illini Books I97 I) (1969) ("[T]he power to be lenient is the power to discriminate." (emphasis omitted)). The concern over the link between discretion and discrimination is not new in criminal law. It was a motivating factor for regulating grand jury selection, see Castaneda v. Partida, 430 U.S. 482, 496-97 \& n.I7 (1977), capital sentencing, see Gregg v. Georgia, 428 U.S. 153, I88-9I (1976), and federal sentencing more generally, see U.S. SENTENCING GUIDELINES MANUAL ch. I, pt. A (2000). Vagueness doctrine arguably also aims at preventing excessive police discretion and its accompanying risk of impermissible classifications. See, e.g., City of Chicago v. Morales, 527 U.S. 41, 7I-72 ( 1999 ) (Breyer, J., concurring in part and concurring in the judgment) (expressing constitutional concerns about unlimited police discretion).

111 See generally H.L.A. HART, THE CONCEPT OF LAW 124-36 (2d ed. 1994).

112 See, e.g., Woodson v. North Carolina, 428 U.S. 280, 303-04 (1976) (plurality opinion) (affirming the constitutional requirement of individualized sentencing in the death penalty context); see also Steiker \& Steiker, supra note 107 , at $38 \mathrm{r}-83$ (discussing the tension between discretion and nonarbitrariness in the death penalty context). In fact, a mandatory death penalty may actually exacerbate unbridled jury discretion because it may invite jury nullification. Woodson, 428 U.S. at $302-03$.

113 See, e.g., William J. Stuntz, The Uneasy Relationship Between Criminal Procedure and Criminal Justice, I07 YALE L.J. I, 7 (1997).

114 See Vorenberg, supra note 43 , at 1562-72.

115 See Davis, supra note 63 , at 35 n. 106 (reporting that "Washington is the only state with [statutory prosecutorial] guidelines"). The Sentencing Guidelines constrain sentencing discretion at the federal level, but the same cannot be said for all state sentencing. See Michael Tonry, Twenty Years of Sentencing Reform: Steps Forward, Steps Backward, 78 JUDICATURE I69, 170 (1995) (reporting that, as of 1995 , more than twenty states had guidelines). 
stitutional risk: if a defendant demonstrates a racial disparity for which no legitimate explanation exists, a court could grant dismissal unless the government could show that it had adopted decisionmaking guidelines ${ }^{116}$ and, where possible, required decisionmaking records. ${ }^{117}$ In effect, statistical disparities would create a presumption of discrimination, but to rebut the presumption, the government would need only demonstrate that it has adopted procedural safeguards that limit discretion and the concomitant risk of discrimination. ${ }^{118}$ This test, which combines statistical and structural elements, is reminiscent of the doctrine dealing with jury discrimination in Castaneda v. Partida, ${ }^{119}$ which held that, when a jury selection procedure is susceptible to abuse, a significant racial disparity is sufficient to establish an equal protection violation. ${ }^{120}$ The Court has subsequently attempted to confine Castaneda to the jury context, ${ }^{121}$ but there is no a priori reason not to extend it to constitutional risks. ${ }^{122}$

From a doctrinal standpoint, any judicially created requirements of record-keeping and guidelines would be essentially prophylactic rules to minimize constitutional risks. ${ }^{123}$ Courts might impose these requirements with varying degrees of specificity depending on the success of early interventions. The substantive details of the guidelines would likely be left to state legislatures because of their polycentric, policy-based nature. ${ }^{124}$ If ultimately unsatisfied, however, courts could

116 Cf. McCleskey v. Kemp, 48I U.S. 279, 365 (1987) (Blackmun, J., dissenting) (advocating the use of "guidelines" for prosecutorial discretion in the death penalty context).

117 Record-keeping may not be possible, for example, in the jury context, given strongly held traditions regarding the secrecy of deliberations.

118 Cf. Kolstad v. Am. Dental Ass'n, I19 S. Ct. 2 I18, 2 I29 (1999) (allowing an employer to evade punitive damages for workplace sexual harassment if the employer has an antiharassment policy and a grievance mechanism in place).

119430 U.S. 482 (1977).

120 Id. at $494-95$. Although the Castaneda elements create only a presumption of discrimination, id., in the context of multiple actors the presumption is very difficult to refute.

121 Cf. Sklansky, supra note 59, at I3I I (implying that the Court has largely confined Castaneda to the jury context).

122 See Castaneda, 430 U.S. at 502 (Marshall, J., concurring) (suggesting that, at least as of 1977 , a statistical disparity and discretionary selection procedures always established a prima facie case of discrimination); Kennedy, supra note 10, at 1427-29 (criticizing McCleskey's distinction of capital sentencing from grand jury selection as "unpersuasive"); see also Developments, supra note 59, at $1552-54$ (suggesting a modified version of the scheme proposed in this Note).

123 See generally David A. Strauss, The Ubiquity of Prophylactic Rules, 55 U. CHI. L. REv. 190 (1988) (observing that constitutional law is replete with prophylactic rules).

124 See Lon L. Fuller, The Forms and Limits of Adjudication, 92 HARV. L. REV. 353, 394-404 (1978) (suggesting that legislatures are the institutions most competent to make decisions that carry multiple and complex repercussions involving many actors). This partnership between courts and state legislatures would parallel the Supreme Court's intervention in capital sentencing in the 1970s. See Gregg v. Georgia, 428 U.S. 153, 188-95 (1976) (plurality opinion). 
offer certain procedures as safe harbors or even as constitutional requirements. $^{125}$

The requirements of guidelines and record-keeping accomplish four important goals. First, guidelines constrain discretion by providing a decisionmaking framework. Concededly, guidelines cannot eliminate all racism in the criminal process, but they can at least minimize it by reducing the range of discretion available to government actors. ${ }^{126}$ Second, record-keeping and guidelines create greater transparency, forcing government actors to make reasoned justifications and deterring them from using impermissible factors. ${ }^{127}$ Third, decisionmaking standards and records provide appellate courts with the necessary tools for meaningful review. ${ }^{128}$ Indeed, even if appellate courts are ill suited for reviewing executive discretion, ${ }^{129}$ the mere threat of review has normative value and may alter behavior. ${ }^{130}$ Finally, the implementation of guidelines benefits all defendants equally - unlike structural injunctions and proportional remedies, it is not a race-based remedy.

3. Potential Concerns. - Discretionary guidelines do, however, have some inherent drawbacks. Naturally, they limit prosecutorial discretion, which the Court has recognized as essential in a resourceconstrained world. ${ }^{131}$ Guidelines also limit the ability of all actors in the system - police, prosecutors, and judges - to dispense individualized justice. ${ }^{132}$ The problem is that catering to the individual case

125 Compare Miranda v. Arizona, 384 U.S. 436, 467-68 (1966) (suggesting a safe-harbor procedure that would satisfy Fifth Amendment requirements but encouraging legislatures to develop their own solutions), with Dickerson v. United States, I20 S. Ct. 2326, 2332-36 (2000) (interpreting Miranda as announcing a constitutionally mandated prophylactic rule).

126 But see Rory K. Little, The Federal Death Penalty: History and Some Thoughts About the Department of Justice's Role, 26 FORDHAM URB. L.J. 347, 478-8I (I999) (noting that despite the Department of Justice's elaborate death penalty review process, federal death sentencing exhibits even greater racial disparities than state death sentencing).

127 If government actors remained undeterred, such records could be used for further litigation. See Harris, supre note 72, at 566 (reporting the statistical evidence of racial disparities that Maryland police generated after a settlement required greater record-keeping of certain traffic stops).

128 See Strauss, supra note 123 , at 196 (suggesting that "clear standards make it easier for a court reviewing the official's action to determine if it was influenced by an impermissible consideration"); $c f$. Indus. Union Dep't, AFL-CIO v. Am. Petroleum Inst., 448 U.S. 607, 685-86 (1980) (Rehnquist, J., concurring) (describing the need for intelligible principles to facilitate judicial review of administrative decisions).

129 See Wayte v. United States, 470 U.S. 598, 607 (1985).

130 For example, the constitutional ban on race-based peremptory challenges established by Batson v. Kentucky, 476 U.S. 79, 100 (1986), may be a paper tiger, see supra note 94, but its "shadow effects" arguably have tangible value. Cf. Cass R. Sunstein, Law and Administration After Chevron, 90 CoLUM. L. REV. 2071, 2112 (1990) (arguing that clear statement rules and the nondelegation doctrine operate as "second-best surrogate[s]" in light of the "intrusiveness and unwieldiness" of large-scale judicial review).

131 See, e.g., Wayte, 470 U.S. at $608-09$ (1985).

132 Cf., e.g., McCleskey v. Kemp, 48I U.S. 279, 314 n.37 (I987) (declaring "discretion essential to a humane and fair system of criminal justice"). 
necessarily undermines the uniformity of legal rules. ${ }^{133}$ Mercy may temper justice, but mercy requires discretion, and discretion allows discrimination. ${ }^{134}$ Thus, the best one can hope to achieve is a balance, ${ }^{135}$ and by retaining but narrowing discretion, discretionary guidelines reduce the risk of discrimination while preserving a modicum of individualized justice.

More fundamentally, critics may ask whether courts, as compared to legislatures, are the appropriate institutions to implement systemic changes. ${ }^{136}$ Legislatures, however, have perverse incentives to draft overinclusive criminal statutes and to defer to prosecutors: broad criminalization maximizes politically popular "law and order" rhetoric, and extensive prosecutorial discretion minimizes legislatures' blame for perceived miscarriages of justice. ${ }^{137}$ In addition, discretionary guidelines are not nearly as intrusive as the structural injunctions described in section II.B. A prophylactic rule requiring discretionary guidelines would mandate only that legislatures constrain discretion, either by legislating directly or by delegating the authority to develop guidelines to police, prosecutors, and trial courts. ${ }^{138}$ A guidelines approach to constitutional risk would leave considerable leeway for local officials to develop their own systems to limit discretion. Only in the face of consistent failure would the judiciary need to increase its involvement. And even if courts shunned more intrusive measures as overly activist, the mere recognition of the problem might spur other branches to develop appropriate remedies. ${ }^{139}$

133 See Callins v. Collins, 5 10 U.S. II 4 I, I 144 (1994) (Blackmun, J., dissenting from denial of certiorari) ("Experience has taught us that the constitutional goal of eliminating arbitrariness and discrimination from the administration of death can never be achieved without compromising an equally essential component of fundamental fairness - individualized sentencing." (citation omitted)).

134 Cf. Steiker \& Steiker, supra note 107, at 39r (explaining how standardless consideration of mitigating evidence makes discrimination possible in death penalty sentencing).

135 See McCleskey, 48 I U.S. at $313 \mathrm{n} .35$ (discussing the essential need to balance uniformity and discretion).

136 See id. at 319 (maintaining that legislatures are the appropriate institutions).

137 See William J. Stuntz, Substance, Process, and the Civil-Criminal Line, 7 J. ConTEMP. LEGAL ISSUES I, I5-Ig (1996).

138 Cf. Strauss, supra note I23, at 200-0I (defending Miranda's prophylactic rule as less judjcially imperialistic than rigid overbreadth doctrines in the First Amendment context because it allows for legislative alternatives).

139 For example, instead of courts imposing prophylactic rules, Congress could legislate guidelines that were "congruent and proportional" to the harms involved. Cf. City of Boerne v. Flores, 521 U.S. 507, 530-33 (1997); TRIBE, supra note 42, \& 16-20, at I5I4 n.97 (speculating that McCleskey left room for Congress to regulate, under Section 5 of the Fourteenth Amendment, state death penalty procedures that discriminate against racial minorities). 


\section{CONCLUSION}

This Note has examined the consequences of a shift in the equal protection context - a move from a traditional particularized harm perspective to a constitutional risk perspective focused on systemic harms. It has also acknowledged the significant remedial difficulties associated with constitutional risk, but by focusing on discretion as the source of most equal protection risks, this Note has proposed a moderate doctrinal change: discretionary safeguards.

To be sure, this Note leaves the project substantially incomplete. Constitutional risk's focus on statistical evidence requires careful discussion of the pitfalls judges face in this area and of how they can develop expertise in response. Additionally, because one need not confine the constitutional risk perspective to equal protection, it may usefully be extended to inform other constitutional doctrines, such as facial challenges and prophylactic rules. ${ }^{140}$ In extending constitutional risk, however, one should remember that shifting to a risk-based view of constitutional law represents a genuine policy decision. Never have laws protected every individual against every risk - to do so is neither practical nor possible. Therefore, one must determine which risks are substantial enough to warrant a remedy. Even more crucially, one must decide if constitutional risk is a transsubstantive doctrine, or whether only some constitutional harms are serious enough to require a more systemic and nuanced look. ${ }^{141}$ All this remains for another day.

140 A cursory examination reveals that the idea of constitutional risk may be latent in many areas of constitutional law. For example, one can view overbreadth doctrine and some facial challenges not as redressing actual harm (as in the case of an as-applied challenge), but as removing a risk of constitutional harm from the plaintiff's environment. The same is true for prophylactic rules, which address not constitutional harms ex post, but the risk of future constitutional harms ex ante. See Strauss, supra note 123 , at $198-200$ (suggesting that levels of constitutional scrutiny are in effect prophylactic rules).

141 Cf. Richard H. Fallon, Jr., As-Applied and Facial Challenges and Third-Party Standing, 113 HARV. L. REV. I 32 I, I 342-56 (2000) (arguing that facial challenge doctrine is not transsubstantive but rather reflects specific doctrinal tests). 